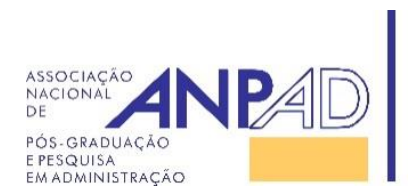

Disponível em

http://www.anpad.org.br/rac

RAC, Rio de Janeiro, v. 22, n. 1, pp. 138-162, janeiro/fevereiro, 2018 http://dx.doi.org/10.1590/1982-7849rac2018170035

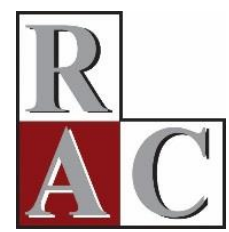

Casos para Ensino:

\title{
Desafios da Gestão Participativa no Museu de São Brás em Portugal
}

\section{Challenges to Participatory Management at the São Brás Museum in Portugal}

Hilda Barbara Maia Cezário ${ }^{1}$ Eduardo Davel ${ }^{2}$ Lorena Sancho Querol ${ }^{3}$

Emanuel Sancho ${ }^{1}$

Museu do Traje, São Brás de Alportel ${ }^{1}$ Universidade Federal da Bahia ${ }^{2}$ Universidade de Coimbra ${ }^{3}$

Artigo recebido em 12.02.2017. Última versão recebida em 18.06.2017. Aprovado em 10.09.2017. Editora Associada: Profa. Anete Alberton 


\section{Um Novo Diretor no Museu ${ }^{(1)}$}

\section{Antonio:}

- Bom dia a todos! Para os que não me conhecem, sou Antonio Braga, o presidente da Fundação Joaquim Viegas Mendonça, que tem a tutela administrativa do Museu do Traje de São Brás. Hoje venho apresentar o Dr. Filipe Rêgo, que assumirá a sua direção a partir de hoje. Alguns de vocês já o conhecem. É um profissional conceituado na área de museus. Desempenhou funções de direção no Museu da Indumentária em Lisboa e, já cá, esteve algumas vezes participando em atividades com o anterior diretor, Álvaro Pires. Bem, melhor será que o Dr. Filipe vos fale.

\section{Dr. Filipe:}

- Bom dia! De fato, estive cá algumas vezes colaborando em ações de inventariação e identificação do rico acervo deste museu, considerado o segundo maior acervo de traje de Portugal, logo após o nosso Museu da Indumentária, em Lisboa. É admirável que tão expressiva coleção seja fruto, basicamente, de doações das comunidades desta terra e do Algarve, decorrente de um importante trabalho de mobilização do nosso querido Padre José Antunes, iniciado há cerca de 30 anos e continuado até aos dias de hoje. Entretanto, acredito que chegou a hora de estabelecermos uma política de rigor com a seleção destes acervos, dando a atenção requerida a esses objetos, para que possamos valorizar o que aqui temos de realmente importante. Espero que a minha experiência de gestão, consolidada durante dez anos em Lisboa, possa contribuir significativamente para a boa condução deste Museu. Além disso - e porque estamos num momento de apresentações - gostaria de que soubessem que a minha formação inicial é em Administração de Empresas, completada mais tarde por mestrado e doutoramento em Museologia.

Enquanto Dr. Filipe continuava a falar, a pequena equipe, juntamente com alguns membros do Grupo de Amigos do Museu ${ }^{(2)}$, ouvia com atenção. Alguns ainda não acreditavam que Álvaro Pires, o antigo diretor, não mais voltaria ao museu. Afinal, fora mais de 20 anos ligado à instituição e conhecido por toda a comunidade de São Brás, inclusive pela extensa e diversa comunidade de estrangeiros do norte e do leste europeu, que constituem estratos significativos e diferenciados no seio da população da vila e também do Grupo de Amigos.

Mesmo nesse contexto, em uma semana de ausência, numa vila com cerca de 5 mil habitantes, muitos ainda não sabiam que Álvaro havia se desligado da Fundação Joaquim Viegas Mendonça, que regia o Museu do Traje. Os motivos eram de natureza particular. Sabia-se que sua família já não morava em São Brás e que esse desligamento aconteceria, mais cedo ou mais tarde. Entretanto, todos sabiam dos constantes aborrecimentos entre Álvaro e a direção da Fundação, que interferia em diversas ações e projetos, perturbando a autonomia de criação e execução. Isso gerava frustrações para os demais colaboradores que viam sua dinâmica de funcionamento sendo alterada sem participarem, como de costume, dos processos de decisão.

O corpo diretivo da Fundação acreditava que ele estava fazendo o seu papel, entendendo que, como gestor, deveria assumir uma liderança forte, dar conta de tudo e todos, centralizando as decisões.

Apesar de contar com vários colaboradores e voluntários em torno dos Amigos, a equipe do Museu do Traje de São Brás de Alportel (MuT) era pequena (Figura 1). Contava com dois colaboradores do quadro fixo da Fundação, além do diretor. Eram funcionários que desenvolveram competências em diversas áreas, desempenhando papéis polivalentes em sintonia com as múltiplas necessidades e características do museu. 


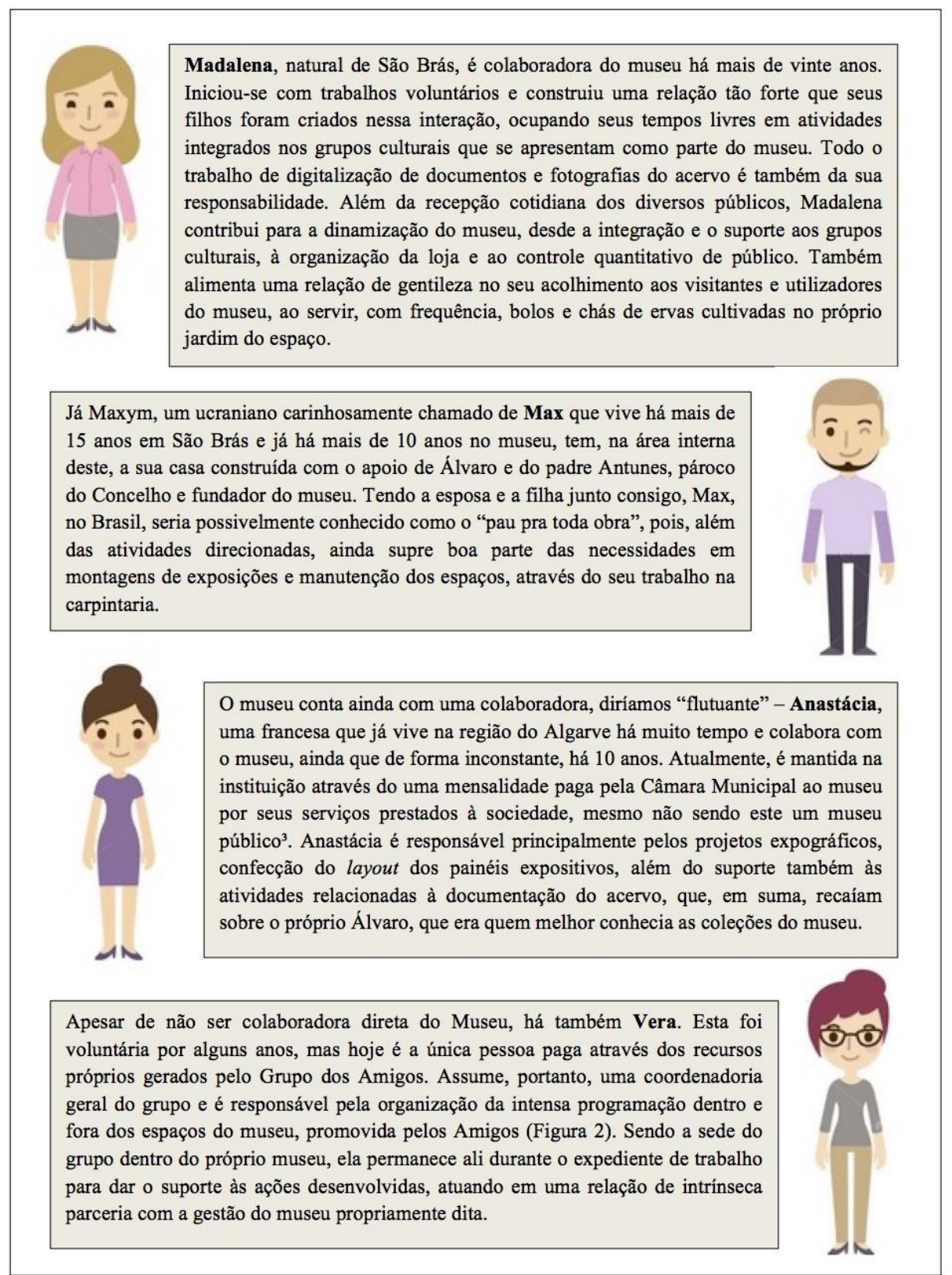

Figura 1. Equipe do Museu do Traje de São Brás de Alportel ${ }^{(3)}$

Fonte: Elaborada pelos autores. Dados da pesquisa.

Para finalizar o seu pronunciamento, Dr. Filipe propunha uma reunião no dia seguinte com toda a equipe, para alinhar expectativas e expor o novo plano de reestruturação da gestão do museu. Ao final, precisou se ausentar e adiar o passeio pelo museu, proposto por Madalena. Adiou também a conversa com os integrantes do Grupo da Fotografia, Memória e Identidade (FMId) ${ }^{(4)}$, pois precisava alinhar algumas informações com a Direção da Fundação.

Pronto! Esse foi o início do dilema criado no MuT, decorrente não somente da mudança de diretor, mas sobretudo do novo modelo de gestão protagonizado pelo Dr. Filipe, mais vertical e centralizador. Logo, a equipe do museu sabia que as ações cultivadas pela ampliação da participação e da autonomia de gestão, por parte de cada um deles e dos sujeitos envolvidos na atuação do museu, não seriam facilmente aceitas por Dr. Filipe. Entretanto, tratava-se de uma teia de atores já imbricada no cotidiano da instituição, ou seja, essa mudança não seria tão simples assim. Restava, por hora, aguardar os próximos passos. 


\section{De qual participação estamos falando?}

Chegada a hora da reunião, Dr. Filipe estava entusiasmado.

\section{Dr. Filipe:}

- Boa tarde a todos! Como a nossa equipe é pequena, fico feliz em contar com a presença de representantes dos Amigos do Museu. Será bastante proveitoso, pois gostaria de anunciar o plano de reestruturação da gestão deste museu. Sei que o Sr. Álvaro adotava um modelo de gestão que denominava de Museu em Camadas (Anexo A). Eu o vi apresentar em alguns encontros. Contudo, sinto a necessidade de estruturar melhor algumas atividades, reorganizar espaços e gestão financeira, fortalecer a base de prioridades deste museu, que é o acervo de trajes. Por isso, neste documento que entrego a cada um de vocês, sistematizei alguns pontos dessa reestruturação (Anexo B). Neste encontro, não precisamos abordar todos os pontos. Gostaria que vocês tivessem conhecimento, pois algumas medidas são muito simples e não é necessário perdermos tempo reunidos, certo?

A equipe, surpresa com o teor do resumo do plano entregue, balançava a cabeça afirmativamente. Porém, estavam atônitos com o que estava por vir. Enquanto isso, Dr. Filipe retomava a fala fervorosamente:

\section{Dr. Filipe:}

- Hoje, vou me ater aos pontos que merecem uma atenção mais emergencial. Vamos por tópicos?

\section{A participação na reestruturação administrativa do museu?}

\section{Dr. Filipe:}

- Meus amigos, vejo uma perplexidade estampada nos seus rostos. Ressalto que não é preciso temor. Saibam que não tenho intenção de desfazer ou destruir nada. Ao contrário, gostaria de potencializar alguns pontos a partir da minha experiência no Museu da Indumentária e contribuir para uma melhor organização e funcionamento deste museu, a partir de algumas ideias que discuti com a própria Fundação. Para isso, mudanças são necessárias. Peço a colaboração de vocês para implementarmos este plano, ainda que não tenhamos tempo suficiente de conversa. Hoje será um pouco corrido e não poderei me deter em discussões de ponto por ponto, ok? - Fazia uma pausa, apenas para se certificar de que todos o estavam ouvindo e retomava o discurso - Vejam, a primeira série de mudanças se refere à reestruturação de algumas rotinas administrativas. Algumas coisas, inclusive, penso que podemos iniciar já na próxima semana. Dentre elas, destaco o fechamento do museu todas as segundas-feiras para manutenção geral, tal como ocorre nos grandes museus em muitos lugares do mundo. Além disso, faremos a implantação da máquina de ponto, como funciona em toda a extensão da Fundação. Para nós, como instituição integrante, convém nos adequarmos à estrutura e compreendermos que este é um cuidado comum de vários espaços, bem como, a uniformização da nossa equipe. Não gostaria que tomassem isso como algo negativo, ok?

\section{Laura:}

- Eu não tenho nenhuma objeção, já que se refere exclusivamente à equipe do museu. Entretanto, não vejo em que essa medida pode gerar desconforto, uma vez que diz respeito a apenas três pessoas. No resumo que nos entregou, vejo que a proposta também busca uniformizar o grupo dos Amigos do Museu. Acredito que isso não será viável.

Laura sabia que haveria impactos dessa medida, entretanto, julgavam-nos tão restritos que mais preponderava o seu viés negativo ao positivo. Dr. Filipe ouvia com atenção e compreendia. Porém, justificava que a uniformização dos espaços da Fundação já era uma demanda antiga e que não via porque não atendê-la, ainda que fosse restrita apenas aos três integrantes do corpo-base do museu - ele, como diretor, Madalena e Max. Dando continuidade à proposta, argumentava: 


\section{Dr. Filipe:}

- Compreendo, porém penso um bocadinho diferente, Laura. Creio que devemos nos adequar ao regimento adotado pela Fundação, lembrando que somos parte dela. O intuito seria conseguirmos que, pelo menos, Anastácia e Vera, como colaboradoras regulares do museu, estivessem submetidas a essa nova forma de funcionamento. Com relação à uniformização do Grupo de Amigos, seria distinta, mas serviria para perceber melhor essas pessoas como colaboradoras do museu.

Vera:

- Devo esclarecer que não pertenço ao quadro de colaboradores da Fundação. Sou contratada pelo Grupo dos Amigos do Museu. Além disso, a minha função obriga-me a ter horários bem mais alargados. É o espírito de voluntário. - Interrompeu Vera, com uma ligeira expressão de estranhamento diante daquela ideia que the parecia descabida. - Da mesma forma, acredito que a uniformização não se adequa ao modelo de trabalho que rege os Amigos. Afinal, o que nos identifica como colaboradores do museu são as ações e os vínculos criados, e não a roupa.

\section{Dr. Filipe:}

- Estou ciente, Vera. Inclusive, admiro a organização do Grupo de Amigos e a relação estabelecida com o museu, apesar de não compreender bem como essa dinâmica acontece. Mas isso envolve outros pontos que gostaria de entender melhor, posteriormente. De antemão, reforço o pedido para uma abertura à proposta. Depois, agendamos um encontro com o grupo dos Amigos para evitar confusão. Sobre Anastácia, acredito que deverá se adequar às normas como os demais membros da Fundação.

Anastácia sinalizava, mesmo a contragosto, que não se oporia a uma determinação da direção, mas destacava que, embora fosse contratada pela Fundação, não se tratava de uma colaboradora regular como os demais. Após sua fala, ouvia-se a concordância em meio a ruídos e expressões de Max e Madalena. Entretanto, esses preferiram não falar. Todos sabiam que a Fundação já havia tentado isso antes. A constante negativa do Álvaro mantivera essa proposta distante, devido à ausência de necessidade desse mecanismo num museu com tão poucos colaboradores remunerados.

\section{Dr. Filipe:}

- Se calhar, esse mecanismo até nos ajudará a demonstrar para a Fundação a necessidade de mais colaboradores permanentes para o museu, diante dos relatos de horários extrapolados que já me fizeram. Além disso, acredito na eficácia da implementação de alguns hábitos de rigor como a pontualidade.

A equipe compreendia o pensamento do diretor, mas acreditava que era uma medida muito destoante da realidade e da dinâmica do museu. Como o cenário era de mudanças, Max e Madalena procuraram não contestar, com receio de aparentarem pessoas que fogem do trabalho, quando na verdade, trabalhavam muito além do horário devido.

\section{A participação na reorganização dos espaços e das finanças?}

\section{Dr. Filipe:}

- Gostaria de falar sobre outros pontos que julgo extremamente importantes. Um refere-se à necessidade de uma reorganização dos nossos espaços internos para uma ampliação da nossa área de exposição. Precisamos expor mais nosso carro-chefe, a coleção de trajes (Figura 2). Considero louváveis as ações socioculturais ligadas ao papel desempenhado pelos centros culturais, desenvolvidas sob a gestão do meu colega. Porém desejo potencializar a ação expositiva, que é a nossa grande vocação. Isso fará de nós um verdadeiro museu. É necessário gerir, adequadamente, as galerias expositivas que são utilizadas pelos Amigos, de forma que outros usos sejam secundários. Outro ponto é a gestão dos recursos provenientes das atividades realizadas nos espaços do Museu. Estou intrigado em como é feita a gestão desses recursos. Preciso ter ciência disso. 

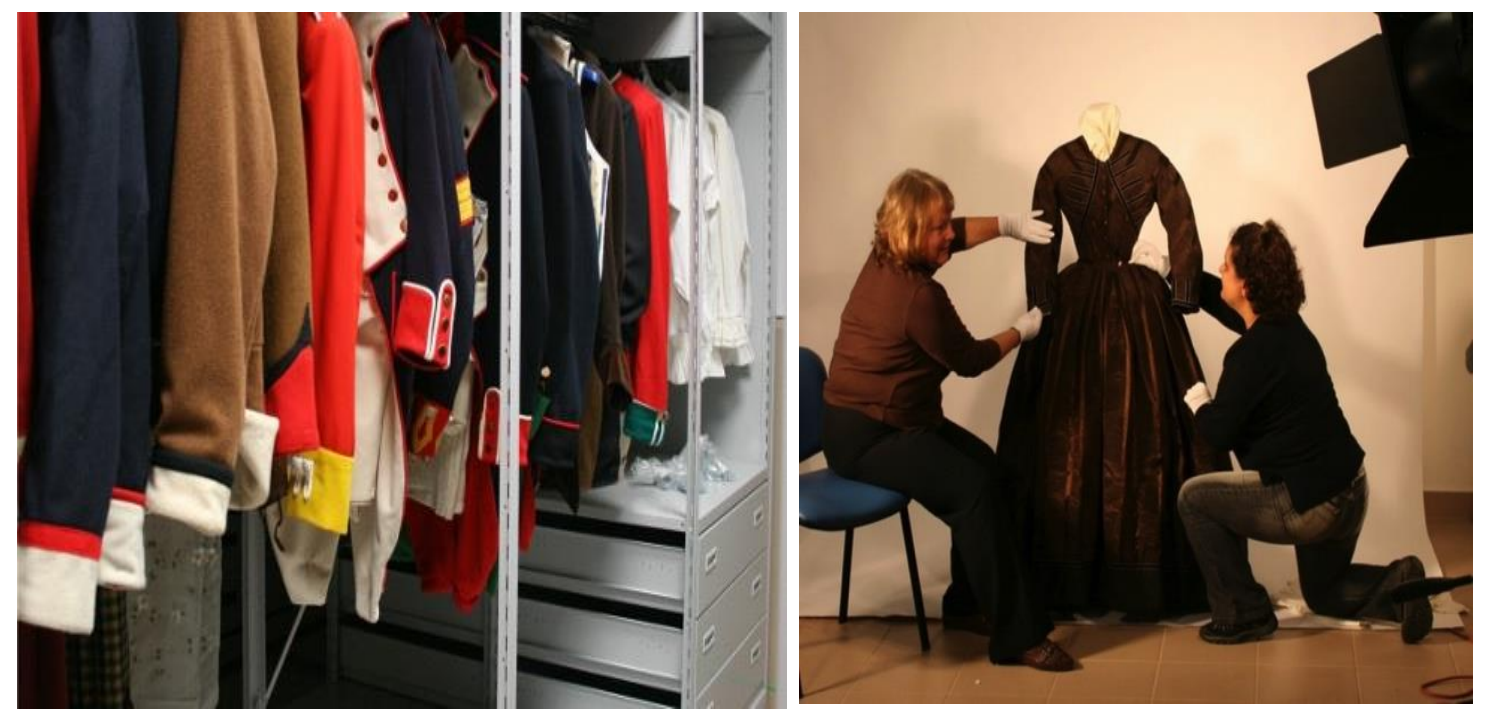

Figura 2. Reserva de Acervo de Traje do MuT

Fonte: Elaborada pelos autores. Dados da pesquisa.

Dito isso, Dr. Filipe passou a palavra à Vera, que lhe explicou como isso vinha se organizando até então. Vera esclarecia que o Grupo dos Amigos assumia a gestão dos espaços do museu, com exceção do edifício sede e das salas referentes às antigas casas agrícolas. Destacava que as galerias polivalentes, a sala do Ateliê de pintura, a sala de aula, a própria sala sede dos Amigos, assim como o bar e o jardim, eram geridos de forma compartilhada (Figura 3). Esses eram espaços muito importantes para a consecução da extensa e rica programação admirada pelo Dr. Filipe nos folhetos. Complementava ainda:

\section{Vera:}

- Então Dr. Filipe, compreendo seus pontos, mas ressalto que essa abertura dos espaços tem sido fundamental para a utilidade deste museu para a população local. Sobre os recursos gerados pela dinamização das ações através do Grupo de Amigos, esclareço que são revertidos no próprio sustento das necessidades do grupo, desde materiais, equipamentos e mobiliários. Muitas vezes, tais recursos são reverberados para melhorias no próprio museu, mas, de fato, têm sido geridos pelo Grupo dos Amigos.

Dr. Filipe demonstrava compreensão com relação a essa utilidade do museu. Porém destacava a questão como algo extra, como atividades que, sem sombra de dúvidas, eram interessantes, mas não deviam ser a essência do museu, tendo em vista a rica coleção que possuíam. Afirmava, assim, que deveria haver um equilíbrio e ser dada maior atenção ao acervo, entendendo que o museu é antes de tudo um espaço expositivo. Em seguida, Anastácia ponderava seu ponto de vista:

\section{Anastácia:}

- Essa é uma questão em que concordo plenamente com Dr. Filipe. Acho importante o trabalho com as pessoas envolvidas pelo museu. Mas sinto a falta desse mesmo cuidado com a renovação de uma exposição voltada para os visitantes ${ }^{(5)}$, que são as pessoas que pagam pela entrada no museu, não é mesmo? 


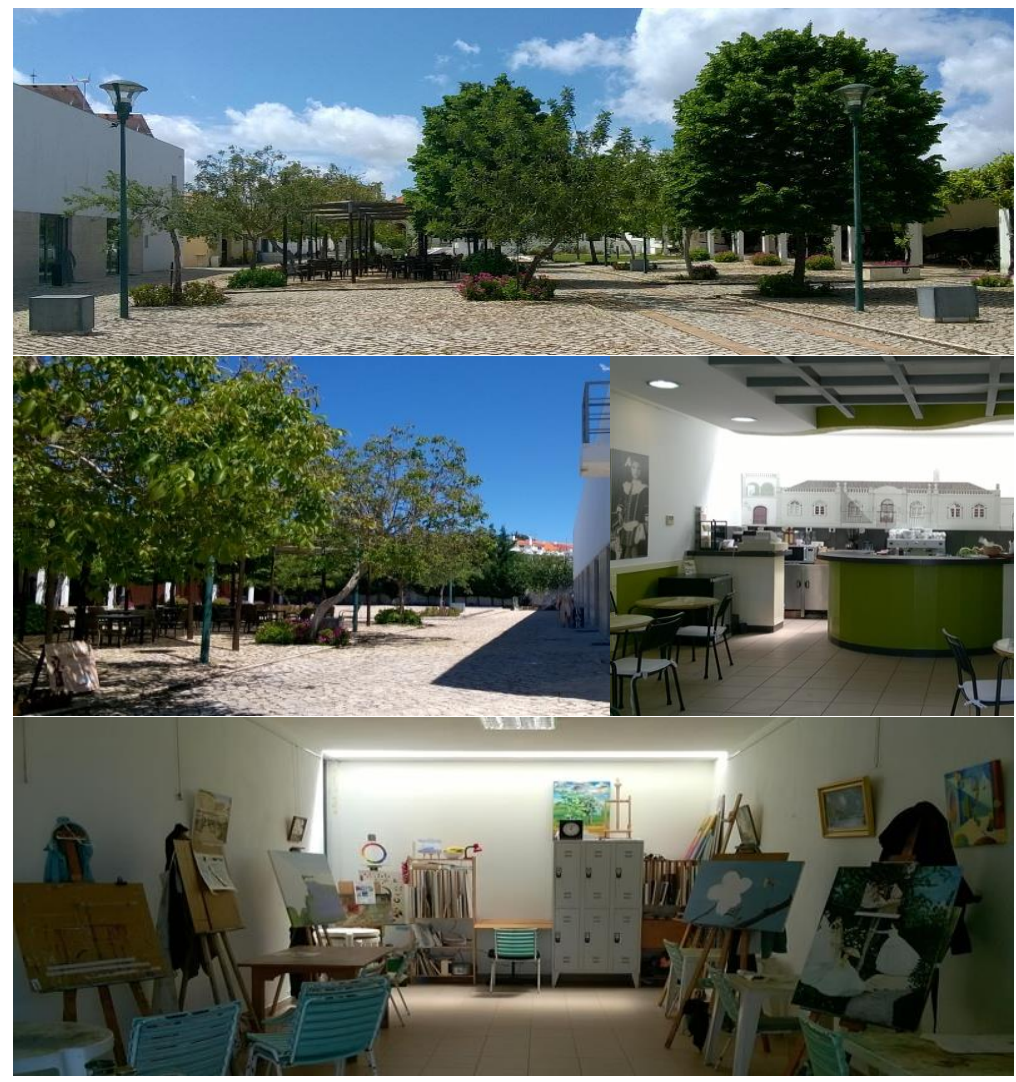

Figura 3. Espaços do MuT (Jardim, Área do Bar e Ateliê de Pintura) Fonte: Elaborada pelos autores. Dados da pesquisa.

Vera:

- Entendo. Porém, a dinâmica vivida pela população local apresenta outras demandas. Quero dizer que, na prática, se as galerias não estiverem disponíveis aos grupos que usam este museu, não teremos mais a vinculação dos dois grupos de teatro, do grupo de fotografia e das aulas de pintura, que também resultavam em mostras. Sem espaço, as mostras não serão desenvolvidas. A polivalência desses espaços sempre foi pensada para a sua ampla utilização em relação às demandas da comunidade. Isso pode ser observado no modelo de gestão do Museu em Camadas (Anexo A) que o Sr. Álvaro sistematizava. Nas camadas, podemos visualizar níveis de interação e vinculação desses grupos e atividades com o museu, das relações mais simples às mais complexas e de longa duração.

Na sequência, Madalena lembrava ainda sobre a existência de outros grupos que utilizavam os espaços do museu, como o Clube do Museu com as Marchas, o Veredas da Memória, as noites de Fado, de Jazz e de Música Clássica, que mensalmente eram realizadas ali.

\section{Dr. Filipe:}

- Ok, ok. Não havia pensado nos impactos dessa questão na dinâmica do Grupo dos Amigos e do próprio museu. Acho-a pertinente e podemos reavaliar. Mas alguma mudança precisa ser feita em relação ao acervo da instituição. Podemos dividir os espaços, não é? Pelo menos, uma das galerias pode ser destinada exclusivamente à exposição e a outra pode manter esse caráter polivalente.

A princípio, esta pareceu ser a opção mais acertada. Vera alertava que precisariam pensar juntos em um novo espaço para o grupo de teatro, para as exposições de fotografia e para os concertos de música clássica que aconteciam em uma das galerias (Figura 4). Por hora, manteve-se uma gestão compartilhada dos espaços, devendo-se manter o diretor ciente de todas as ações e eventos a serem realizados no espaço do Museu. 


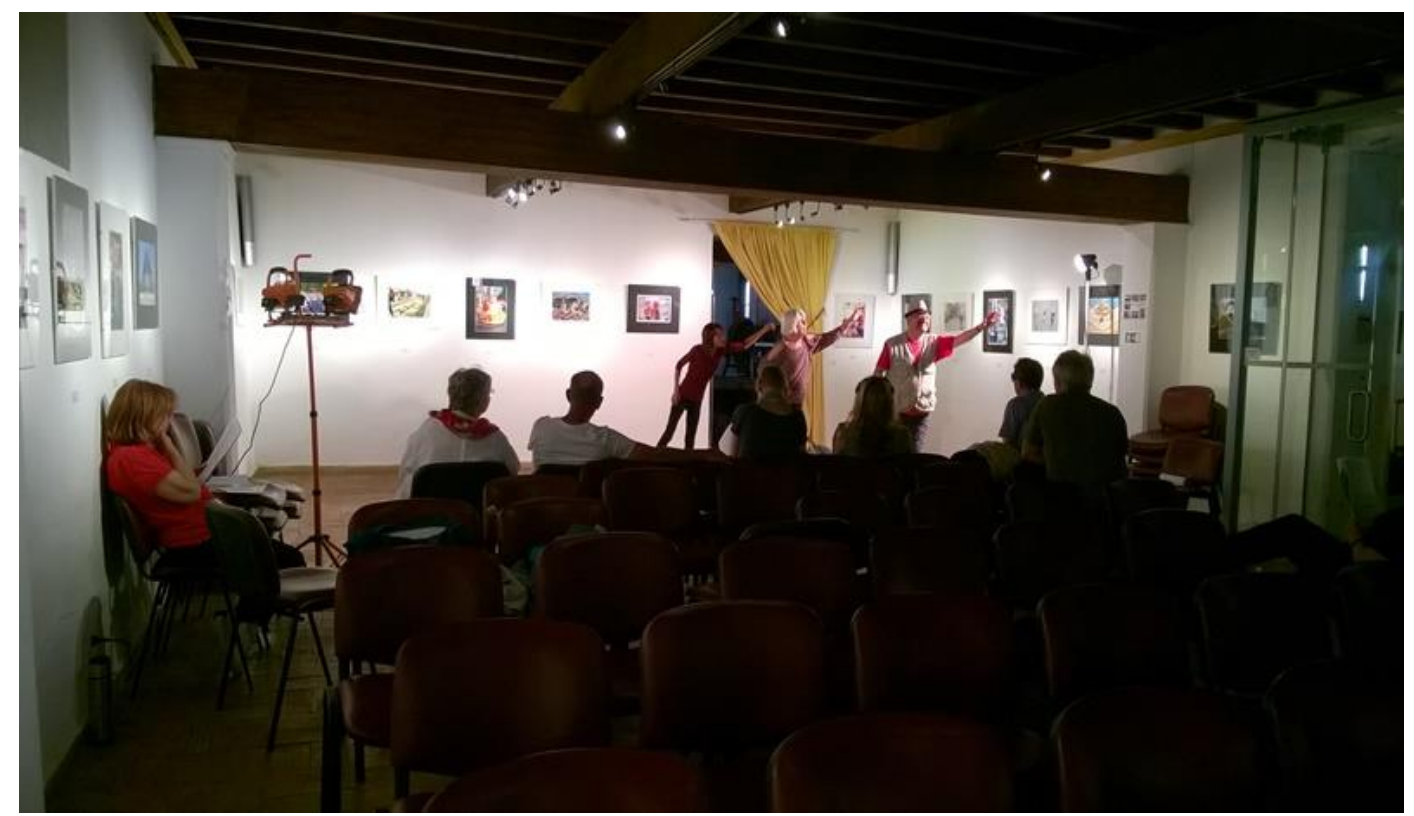

Figura 4. Galeria "Antiga" MuT - Ensaio do Grupo de Teatro na Galeria Fonte: Elaborada pelos autores. Dados da pesquisa.

\section{Dr. Filipe:}

- Já sobre a gestão das finanças, o museu precisa não apenas ter ciência. Precisa ter uma participação mais clara e efetiva na gestão desses recursos, afinal, as atividades são desempenhadas por um Grupo de Amigos do Museu e não por um grupo qualquer.

\section{Vera:}

- Dr. Filipe, esse ponto precisará de maior discussão, envolvendo os demais membros do Grupo de Amigos, ou, pelo menos, do grupo coordenador. O modelo que permitiu o desenvolvimento dos Amigos sempre teve como base a partilha de responsabilidades e a liberdade de gestão dos fundos gerados, dentro de um ambiente de diálogo e de total confiança mútua. Perante essa nova política, receio que os nossos colaboradores voluntários sintam a quebra de confiança e se afastem.

Diante do exposto, Dr. Filipe pediu o agendamento de um encontro com o grupo coordenador na semana seguinte, uma vez que julgava arriscado estar à frente de uma instituição sem ter o real controle sobre seus gastos e suas receitas.

\section{A participação nas mudanças da gestão de pessoal?}

Dr. Filipe dava continuidade destacando a necessidade de reformular o organograma do museu, definindo mais claramente os setores e a formação de uma equipe técnica qualificada. O acompanhamento dos setores deve ser realizado por meio de relatórios mensais, para estar ciente mesmo quando não estiver presente no museu.

\section{Dr. Filipe:}

- Precisaremos também de uma secretária geral da direção, para centralizar os agendamentos de visitas, os usos do veículo do museu e dos espaços, as planilhas de quantitativo de visitantes e o acompanhamento financeiro. Enquanto não temos um funcionário para isso, Madalena poderia realizar essa função, o que acha? 


\section{Madalena:}

- Nunca fiz esse tipo de trabalho, mas tentarei fazer o meu melhor. Preciso avisar que essa nova função acarretará ausências em algumas atividades, pois não tenho condições de realizar tantas coisas ao mesmo tempo. Gostaria de aproveitar para saber como será a continuidade do projeto de fotografia (Figura 5). Além de Dona Maria e de Dona Joaninha, que estão presentes hoje, outros integrantes questionaram depois de saberem da saída do Sr. Álvaro, que acompanhava semanalmente esse grupo.

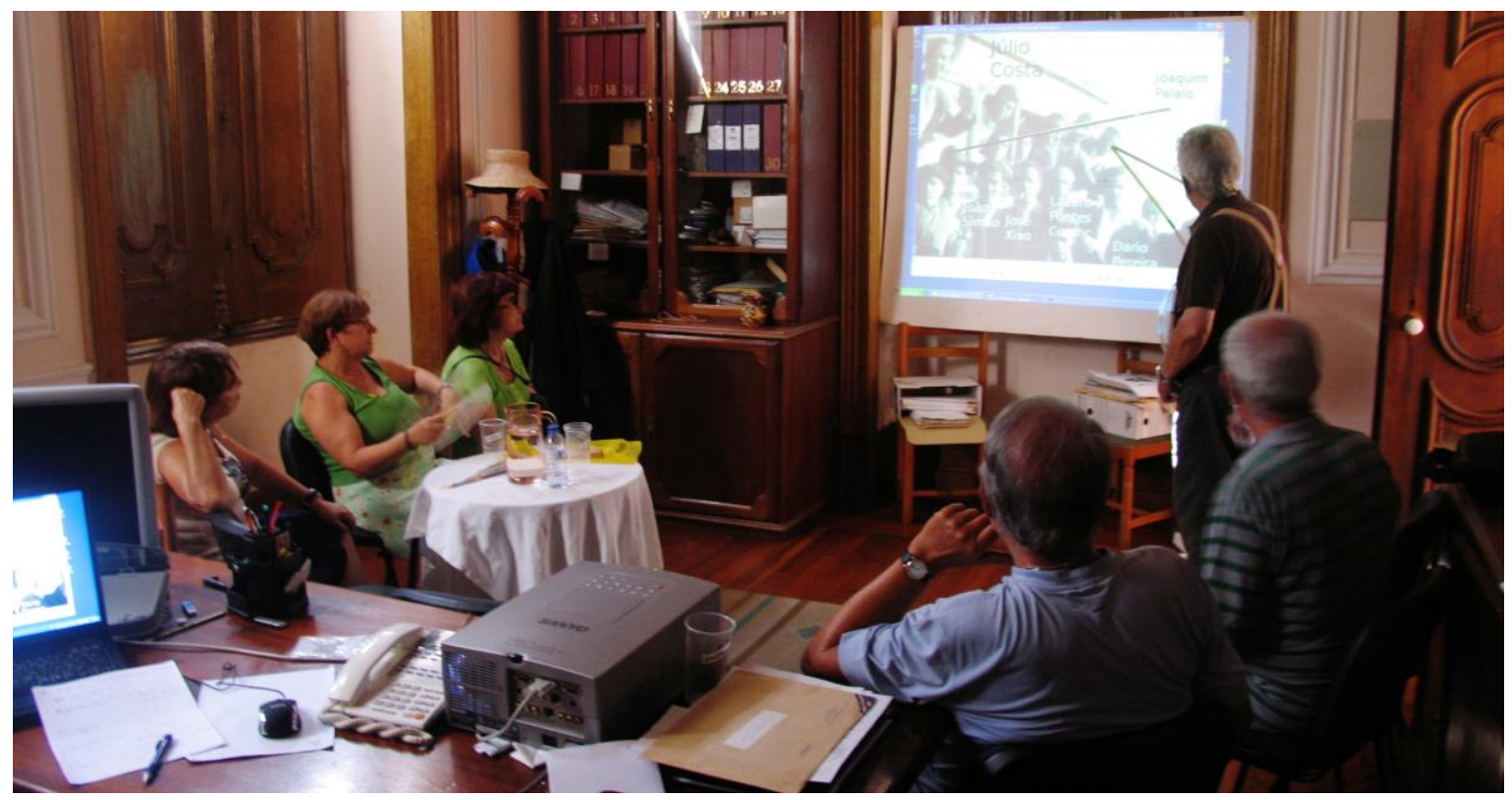

Figura 5. Grupo de Fotografia, Memória e Identidade do MuT Fonte: Elaborada pelos autores. Dados da pesquisa.

\section{Dr. Filipe:}

- Bem, sobre isso, de pouco adianta darmos continuidade a uma ação sem a percepção da dimensão global do seu impacto. Já tive a oportunidade de ouvir o Álvaro apresentar esse trabalho em um encontro de museus e sei da sua importância. Sei também que, por trás, há um trabalho consistente de sistematização que permitiu a construção de uma base de dados riquíssima. Ainda não tive tempo de entrar em contato com ele para compreender o seu modelo organizativo. Digo isso para que compreendam que não pretendo acabar com o projeto, mas não tenho possibilidade de me envolver como ele fazia. Primeiro, porque não estarei todo o tempo aqui, mas sim entre o Museu da Indumentária e o MuT. Segundo, porque há muitas outras demandas sobre um diretor. Ao focar em apenas uma, as outras, talvez mais necessárias, podem ficar vulneráveis, como as exposições e o tratamento do acervo, como havíamos discutido. Sobre isso, notei que não temos nenhum profissional qualificado na equipe para esse trato com a diversidade de acervo que temos. Somente eu não conseguirei dar conta. Por causa disso, já estou em articulação com a Fundação para a integração parcial de um técnico do Museu da Indumentária à nossa equipe, para garantirmos uma assistência qualificada com relação à preservação dos têxteis. Ele será encarregado de uma supervisão, pois não estará em tempo integral na instituição.

\section{Dona Joaninha:}

- Desculpe a intromissão. Sobre o grupo de fotografia, gostaria de me oferecer como voluntária para as atividades de registro. O Sr. Álvaro, já há algum tempo, vinha me mostrando como inserir os dados no programa que usava no computador. Era esse o papel que ele cumpria nos encontros, uma figura de mediação e estímulo ao grupo, sempre com uma carta na manga caso nós mesmos não trouxéssemos nossos registros pessoais e familiares. 
Surpreso com a disponibilidade demonstrada por Dona Joaninha, Dr. Filipe agradeceu a ela. Porém, reforçou a necessidade de participação de alguém da própria equipe do museu para tal atividade.

\section{Madalena:}

- Dr. Filipe, esta é uma das atividades por que tenho muito apreço. Os participantes são todos moradores antigos, nascidos e criados na nossa terra. Não acompanhava toda a dinâmica em sala, pois tinha que ficar na recepção. Vinha servir um chá e um bolo para animar as memórias e interagia com aquela dinâmica. Adoraria ficar responsável por isso. Entretanto, já me destes outras demandas, além da própria recepção.

\section{Dr. Filipe:}

- Entendo, Madalena. Veremos como organizar essas atividades da melhor forma. Como você apontou, tem a recepção e as outras atividades que são mais adequadas para sua atuação. Agora, retornando a nossa pauta, ainda sobre os relatórios, gostaria de pedir o mesmo a Anastácia e a Laura. Sei que Laura desempenha com muito boa vontade uma atividade de extrema importância para a conservação do nosso acervo, mas precisaria de um rigor maior com essa questão. O acervo de têxteis é um dos mais frágeis que temos. Com a chegada do colega do museu de Lisboa, teremos o devido acompanhamento desse trabalho, Laura. O que acha?

\section{Laura:}

- Eu faço o que posso por esse museu. Porém, o faço com o rigor que talvez outras instituições portuguesas não tenham. Afinal, procuro sempre me orientar pelos grandes museus, como o Louvre e o próprio Museu Britânico, que conheço bem, pois, como deve saber, sou inglesa. Peço que me avise quando eu for necessária. Com licença, preciso me retirar. Já tinha um compromisso marcado neste horário, quando esta reunião foi proposta ontem.

\section{Dr. Filipe:}

- Espero que tenha compreendido a proposta Laura. Meu desejo é aperfeiçoar os procedimentos do museu. Bem, creio que por hoje é só. No decorrer dos dias, trabalharemos os demais pontos do plano, certo?

\section{Laura:}

- Não se preocupe. Creio que todos nós entendemos muito bem!

Já de pé, Laura saía ligeiramente da sala. Entre os demais, os olhares e o silêncio permaneciam enquanto se levantavam, recolocando as cadeiras em seus lugares.

\section{Nostalgia da gestão participativa no MuT: O que é lembrado?}

Dois meses se passaram desde aquela reunião, e muitas coisas mudaram naquele Museu. Eram 13 horas de um dia qualquer e, mais uma vez, Alfredo, responsável pelo Bar Café do Museu, lembrava nostálgico que, naquele horário, a pequena equipe do museu se reunia ao redor de uma mesinha no jardim para a bica, após o almoço. Era interessante ver como aquela prática havia se instalado no convívio entre aquelas pessoas, inclusive o rodízio do pagamento da rodada de cafés ao Alfredo, que, por sinal, já sabia o gosto de cada um. Hoje, entretanto, parece que seria diferente. Um após outro, foi chegando e se sentando, com exceção do novo diretor.

\section{Alfredo:}

- Que alegria, amigos! Há quanto tempo não se reuniam mais aqui. Pensei que haviam encontrado um café melhor. Mas que caras são essas? Onde está o Dr. Filipe? 


\section{Madalena:}

- Cara de cansaço, Alfredo. Hoje, precisamos marcar para estarmos juntos, pois agora, além do ponto que não nos permite essa flexibilidade no horário de almoço, temos também uma série de relatórios para fazer. Acho que a única que não sofre com isso é você, não é Florência? - A pergunta era dirigida, em tom de brincadeira, à Florência, colaboradora rotativa enviada pelo Fundo de Desemprego para ajudar na manutenção e na limpeza dos espaços do museu.

\section{Florência:}

- Sim, sim... O Dr. Filipe não pediu nada para mim. Na verdade, ele nunca me disse nada. Às vezes, me pergunto se ele sabe que estou aqui. Já não é a mesma coisa, pois vocês sumiram. Ficam todo o tempo em frente a suas máquinas e mal conversamos mais.

\section{Anastácia:}

- Estamos a trabalhar e trabalhar, Florência! - Rindo momentaneamente. - Confesso que o trabalho tem sido demasiado cansativo. Sempre fomos poucos para muitas coisas. Mas agora, parece que as coisas ganharam outro peso. Eu, por exemplo, além da elaboração de inúmeros documentos e relatórios que ele tem solicitado, estou trabalhando na montagem da nova ala expositiva, apenas de trajes. Laura está me apoiando, apesar de ter me falado que iria me auxiliar por consideração a mim. Sei que concordei com o Dr. Filipe, mas não vejo aonde essa exposição poderá chegar. Quantos especialistas em trajes recebemos entre nossos visitantes turistas? Falando na Laura, olha ela ali...

\section{Laura:}

- Boa tarde! Só vim porque precisamos conversar e não apenas tomar café. Quero compartilhar algumas preocupações que já vinha conversando com Vera, Clive, fundador do nosso grupo, como vocês sabem, e outros membros dos Amigos. Eu não sei se continuarei com o trabalho que fazia no museu. Sempre estive disposta a colaborar com o meu melhor. Mas, meu trabalho é voluntário, não sou paga para fazer relatórios, como ele quer. Fiquei bastante chateada. Eu tinha uma sistematização, ainda que simples, daquilo que fazia. Passei pra ele. Bastava pedir e não tratar como se aqui as coisas não tivessem ordem e que o meu trabalho fosse feito sem rigor. Logo eu? Sem rigor? Pois que chame, então, o seu amigo profissional. Não quero falar somente dessa questão pessoal, pois a desmobilização dos Amigos do Museu está forte.

Ouvindo os relatos, Alfredo balançava a cabeça e comentava sobre o esvaziamento do museu, e a contínua diminuição até mesmo dos frequentadores assíduos. Registrava que as vendas iam de mal a pior e que não sabia até quando conseguiria manter o acordo da abertura do Bar em tempo integral, por conta do prejuízo que vinha tendo.

Vera:

- Alguns grupos deixaram de se reunir aqui devido à falta de espaço. Além disso, aquelas pequenas inaugurações das pinturas e das fotografias dos Amigos farão falta, pois eram uma forma de arrecadar para o Bar, mesmo sendo bimensais. As pessoas se queixam da utilidade restrita do espaço da antiga galeria.

\section{Madalena:}

- Ai, não me falem! E aquele serviço de secretária da direção? Agora, todos que chegam ao museu para falar com o diretor, tenho que interpelar, mesmo o senhor Agnaldo, acreditam? Fiquei constrangida em solicitar que ele aguardasse na recepção enquanto avisava o Dr. Filipe. Ele, que foi provedor durante 30 anos e sempre nos ajudou em tudo. O diretor me indicou que eu deveria proceder com todos dessa forma. Sinto que algumas pessoas estão me olhando torto, como se eu quisesse demonstrar alguma superioridade. Preferia outras tarefas como o acompanhamento do FMId... Mas, estas nem estão 
acontecendo... Enquanto isso, fico em maus lençóis com as pessoas e sigo fazendo relatórios financeiros e quantitativo de visitantes.

\section{Vera:}

- Pelo menos os visitantes repentinos parecem ter aumentado. Uma pena que mal chegam a consumir no museu ou usufruir do espaço para além da visita à exposição. Compreendo o Dr. Filipe. Concordo em parte com o que quer fazer, e talvez essa centralização exacerbada inicial seja apenas para tomar pé de tudo. No entanto, creio que ele ainda não conseguiu ver as potencialidades do ambiente que este museu já tinha instaurado. Naquela primeira reunião, percebi que o diretor não encarou como uma solução a disponibilidade apresentada pela Dona Joaninha, algo que, sem sombra de dúvidas, teria sido aproveitado na gestão passada. Talvez, Álvaro já estivesse preparando o grupo para essa autonomia total, como a própria Dona Joaninha relatou. Até hoje, o grupo não conseguiu se reunir mais por falta de um supervisor. Eu cheguei até a me oferecer. Mas, depois da extinção de algumas ações dos Amigos do Museu, eu passo muitos dias fora, acompanhando e dando suporte às atividades que ocorrem em outros espaços externos ao museu que se disponibilizaram para os receber. Creio que ele não faz isso por mau juízo, mas sim, por acreditar nessa centralização para seu modelo de gestão.

\section{Madalena:}

- Meu coração doeu, outro dia. Chegou aqui o seu Carlito, do FMId, com algumas fotografias inéditas e antigas. Ele queria mostrar aquela raridade para o Dr. Filipe e, quem sabe, conseguir reativar o grupo. Disse-me que já estava tudo organizado, precisavam apenas do espaço. Não teriam despesa com mais ninguém; comprometer-se-iam a seguir as orientações já passadas pelo Sr. Álvaro. Entretanto, ele aguardou, aguardou e aguardou na recepção. Dr. Filipe não podia atendê-lo, pois estava numa longa reunião com a cúpula da Fundação.

Seguindo os relatos, Vera contava que essa falta de autonomia dos grupos tinha sido motivo de discussão na reunião que houve entre o Dr. Filipe e o grupo coordenador dos Amigos.

Vera:

- Falávamos da falta de autonomia financeira. Por vezes, pensei que não conseguiríamos sair dali às boas e que logo o grupo de Amigos esvair-se-ia do museu. Por outro lado, o diálogo franco e aberto, bem como a exposição clara das tensões, contribuiu de algum modo para visualizarmos as condições e as posturas dos outros. Dr. Filipe nos contou da pressão da Fundação para tomar nota de tudo que é reserva financeira que perpassa a instituição. O fato é que o MuT está sob um novo perfil de gestor, que, aos poucos, está implantando um outro modelo de gestão, mais centralizado e verticalizado.

\section{Anastácia:}

- Sem dúvida, estamos a falar de outro modelo de gestão. Sinto que o Dr. Filipe não compreende bem o trabalho que era desenvolvido anteriormente, apesar da sua proximidade com a instituição. $O$ trabalho que fazíamos, com autonomia e acessibilidade da população local, está sendo confundido com a ausência de um controle efetivo. O Álvaro deixava claro que o significado deste museu era sua utilidade para esta terra. Queria que o museu fosse tão necessário numa sociedade como um hospital, uma escola... Muitas pessoas que estavam sempre aqui, estariam em hospitais e em busca de remédios se não tivessem este espaço de socialização. Ainda que houvesse queixas sobre as exposições, era uma gestão mais próxima da comunidade. Preocupava-se com a integração e o equilíbrio entre os agentes da terra e os tais agentes especialistas na própria estrutura e dinâmica do museu.

Alguns minutos se passaram enquanto a equipe continuava a falar. Alguns dos presentes estavam extremamente chateados com as mudanças instauradas. Outros, mais mediadores, compreendiam os pontos positivos e os negativos dos modelos diferenciados de gestão. Foi quando Vera propôs ao grupo uma conversa franca com Dr. Filipe, destacando que uma gestão participativa possui diversos desafios e que esse era um deles. Precisavam gerir os conflitos levantados e, para tal, nada melhor do que um 
diálogo aberto. Acreditavam que o caminho diante dessa nova realidade era buscar soluções em conjunto.

Vera:

- Percebo uma abertura do Dr. Filipe para ouvir o que consideramos como problemas. Vamos apresentar nossas relações e dinâmicas mais horizontalizadas. Vamos dialogar sobre as possibilidades dessa atuação para o pleno funcionamento deste espaço. A rede de cooperação já instituída neste museu deve servir não apenas como exemplo, mas como meio para a construção de novas estratégias frente aos desafios encontrados.

Max:

- Pronto! Vamos chamá-lo para uma reunião. Isso poderá parecer estranho para ele, que vem dos moldes de um grande museu. Mas, se ele realmente admira e considera relevante o que fazíamos aqui, vamos arriscar, não é?

\section{Podemos Reconstruir a Participação do Passado no Presente?}

A confiança de Max, que ouvira tudo calado, pareceu contagiar o grupo, que, a partir daquele único encontro, lembrou-se de tudo o que estava em jogo ao mudar dinâmicas importantes para o funcionamento do museu. Haveriam de encontrar um caminho alternativo com o Dr. Filipe. Porém, a participação de todos era fundamental para enxergar os pontos positivos e negativos das medidas tomadas. O diálogo franco parecia ser a única e, se calhar, a melhor opção.

Coincidentemente à sinalização positiva de todos, o Dr. Filipe aparecia no portão. Era um sinal!

\section{Laura:}

- Dr. Filipe, boa tarde! Um momento, por favor. Gostaríamos de conversar com o senhor! - Dizia, com um grande sorriso convidativo.

\section{Dr. Filipe:}

- Olá, Laura, boa tarde! Queria mesmo falar contigo. - Respondia igualmente sorrindo, porém com ar preocupado. - Quase não a vi mais, após aquela primeira reunião. Fiquei a pensar se de algum modo a ofendi com minhas palavras ou propostas. Li seus relatórios e queria ouvi-la e desfazer qualquer mal entendido.

\section{Laura:}

- Não se preocupe mais com isso. - Disse-lhe, encaminhando-o em direção ao grupo que permanecia reunido. - Hoje precisamos tratar de assuntos mais relevantes do que a minha chateação.

\section{Dr. Filipe:}

- Mas quem, então, quer conversar comigo? - Indagou, curioso.

Laura:

- Todos! - Mais uma vez respondia sorrindo, afavelmente, enquanto chegava até o grupo, com intuito de retirar aquela preocupação que insistia em franzir o cenho do Dr. Filipe.

Mesmo espantado, o Dr. Filipe sorria em resposta àquela estranha situação, em que todos os seus colaboradores o olhavam de modo acolhedor, como que pedindo que se sentasse junto a eles. 
Alfredo:

- Aceita um café, Dr. Filipe?

Pronto! Alfredo dera o ponta pé inicial àquela tarde de conversa e desafios.

\section{Notas}

${ }^{1}$ Neste caso, as narrativas são mesclas entre ficção e realidade, decorrentes do estudo de caso da experiência do museu apresentado, baseado em dados coletados por meio de entrevistas semiestruturadas, documentos e observação participante.

${ }^{2}$ Os Amigos do Museu é uma organização não formal que existe há 18 anos. É composta por mais de 800 membros (destes, mais de 50\% são de origem estrangeira) e possui uma intensa diversidade de ações e eventos dentro e fora do museu. Surgiu a partir da iniciativa de Clive Newton, cidadão inglês residente na zona que buscou o apoio do museu para realizar as oficinas e exposições de arte que organizava com outros amigos. A partir dessa abertura, outras ações foram ganhando forma e outras pessoas se aproximando, diversificando a programação e a oferta de atividades no museu.

${ }^{3}$ Em Portugal, os conselhos, também chamados de municípios, têm por norma o seu próprio museu municipal tutelado pela respectiva Câmara por norma. A Câmara Municipal de São Brás de Alportel, apesar de desenvolver algumas iniciativas museológicas, reconhece, no Museu do Traje, uma instituição que promove boa parte dos serviços públicos de natureza cultural que seriam de sua responsabilidade. Esse fato traduz-se num protocolo de cooperação entre a Câmara e o Museu/Santa Casa da Misericórdia, renovável a cada ano, que o remunera pelo serviço público prestado, suprindo a contratação de mais um profissional para o museu.

${ }^{4}$ FMId (Projeto Fotografia, Memória e Identidade) é um grupo de trabalho do Museu do Traje com mais de uma década de atividade participativa, dedicada à recolha de fotografias de família. As imagens são digitalizadas e as memórias a elas associadas são identificadas e registradas em reuniões que acontecem todas as quintas-feiras, ao longo do ano. Já foram integradas cerca de 600 famílias, num total de 50.000 imagens. Cada família tem, assim, a sua conta corrente de memórias no museu.

${ }^{5}$ O Museu do Traje adota uma postura diferente para com os diversos públicos que visitam o museu, utilizando o conceito de cidadãos-clientes ao invés de públicos (Vitor, I. (2005). Os Museus e a qualidade. Distinguir entre museus com "qualidades" e a qualidade em museus (Dissertação de mestrado). Universidade Lusófona de Humanidades e Tecnologias, Lisboa, Portugal). As pessoas que, habitando ou não o território do Museu, utilizam-no de forma distanciada e esporádica, são consideradas como público visitante. As pessoas que o frequentam regularmente - e com as quais se estabelece uma interação enriquecedora, social e cultural para ambas as partes, são consideradas utilizadoras. 


\section{ANEXO A}

\section{Modelo de Gestão Participativa do MuT - "Museu em Camadas"}

\section{MODELO PARTICIPATIVO DO "MUSEU EM CAMADAS"}

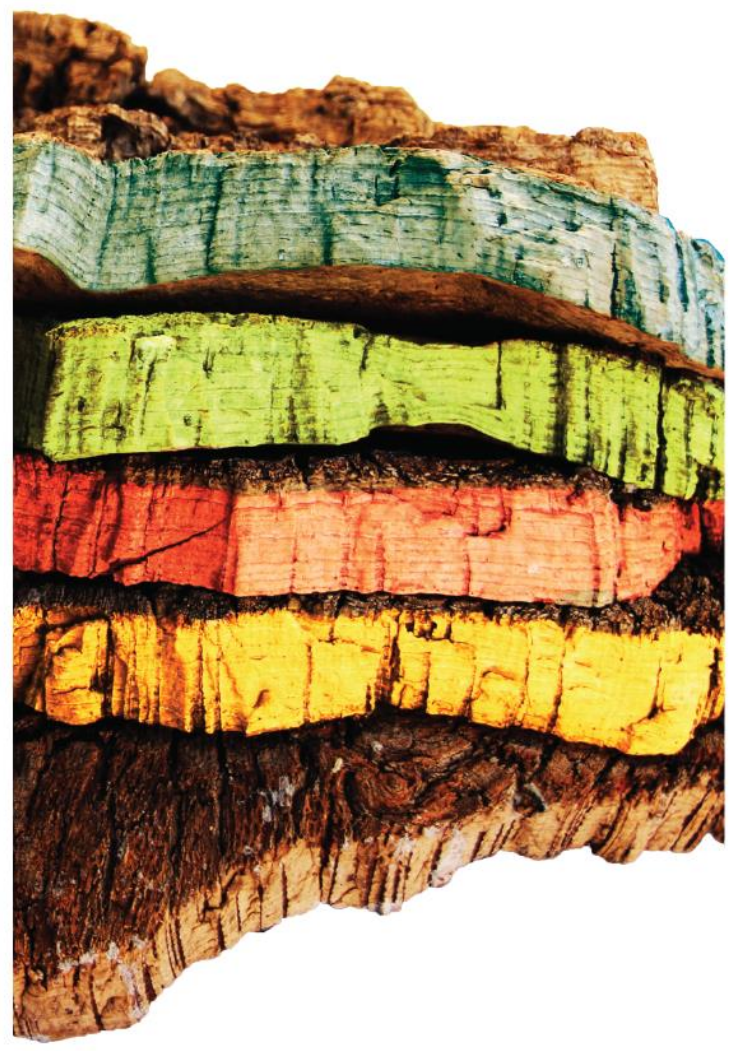

MUSEU VISÍVEL

FUNÇÕES MUSEOLÓGICAS TRADICIONAIS

- EXPOSIC̣ÃO

- MANUTENÇÃO DE EDIFíCIOS E JARDINS

- INVESTIGAÇÃo E PUBLICAÇÃO

- SERVICCO EDUCATIVO
- RESERVAS TÉCNICAS, INVENTÁRIO E CONSERVACÃO

MUSEU DO DIA A DIA

DINÂMICAS SOCIOCULTURAIS

- AMIGOS DO MUSEU

- CLUBE DE JAZZ

CORO DOS AMIGOS

GRUPOS DE FADO \& MÚSICA CLÁSSICA

CLUBE DE FOTOGRAFIA

- CLUBE DE ARTE

DEARTES DRAMATICAS

AL APER MUREU GRUPO DE ANIMACAO SOCIOCULTURAL

\section{MUSEU INTEGRADOR}

PROJECTOS COLABORATIVOS

- ATELIER DE DESIGN MICROEMPRESA INDEPENDENTE DE DESIGN GRAFICO E COMUNICACGÁC

- MUSEU A MEDIDA MICOEMPRESA INDEPENDENTE DE MUSEOGPAFAA

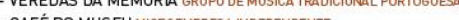

- CAFE DO MUSEU MICROEMPRESA INDEPENDENTE

LOJA DO MUSEU MIICROEMPRESA DELTERATURA EARTESANATO LOCAL.

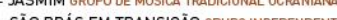

\section{MUSEU DO TEMPO LONGO}

VALORES, CAUSAS EÉTICAS

MUSEUVERDE PROJETO DE SUSTENTABILIDADE AMBIENTAL

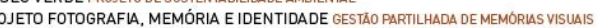
- PROJETO ESCOLA NO MUSEU EDUCACÁO PATRIMONIAL

- PROJETO 100 ANOS DEPOIS EXPOSICÁO PARTICIPATIM

NÚCLEO MUSEOLÓGICO DO ALPORTEL MUSEOLOGLA COMUNITÁRIA

CO-PRODUTION I EMANUEL SANCHO | LORENA QUEROL I TIAGO FERREIRA (behance. net/tigferreira)

Fonte: Criado no âmbito do Projeto SoMus "Society in the Museum: study on cultural participation in European local museums". Coprodução de Sancho-Querol, L., \& Sancho, E. (2015a). How can museums contribute to social and cultural change? (p. 225). In J. T. Jensen \& I. B. Lundgaard (Coords.), Museums: Citizens and sustainable solutions (pp. 212-231). Denmark: Danish Agency for Culture. 


\section{ANEXO B}

\section{Plano de Reestruturação da Gestão MuT}

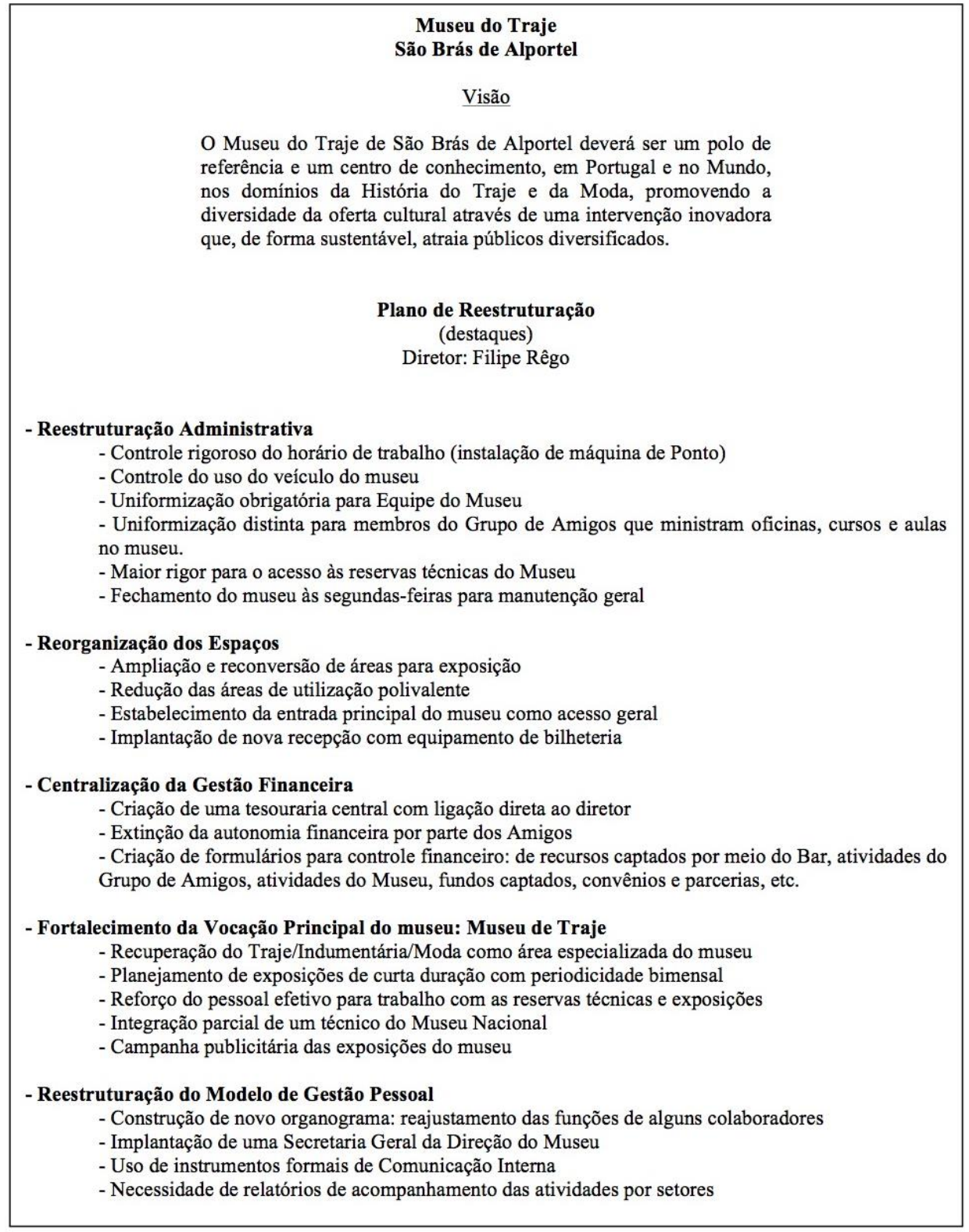

Fonte: Elaborada pelos autores. 


\title{
Notas de Ensino
}

\section{Resumo}

Uma organização, ao mudar de diretor, corre o risco de ver modificado seu modo de gestão. Neste caso para ensino, a mudança de diretoria de um museu comunitário tornou-se uma situação-problema ao confrontar dois modelos distintos de gestão. De um lado, um mais horizontal, baseado em processos de autonomia de grupos que se articulam em rede, e, do outro, uma mais vertical e centralizadora de processos e poderes. $\mathrm{O}$ foco recai sobre uma instituição que é referência da museologia comunitária no contexto europeu: o Museu do Traje de São Brás de Alportel (Portugal). O dilema nos permite compreender e aprender sobre novas dinâmicas participativas no campo da gestão museal, identificando de forma mais específica práticas de mobilização e potencialização da participação social, bem como as competências coletivas necessárias para uma liderança compartilhada. $\mathrm{O}$ caso busca contribuir com a formação de gestores e lideranças comunitárias que se confrontam, frequentemente, com a ausência de instrumentos adequados no momento de levar adiante um projeto coletivo de natureza cultural como é o museu comunitário. Além disso, o caso pode ser útil a todos os interessados nas questões da gestão participativa de organizações.

Palavras-chave: gestão participativa; gestão de museus; Museologia Social; participação; Museu do Traje em São Brás de Alportel.

\begin{abstract}
As an organization changes its director, it takes the risk of changing its way of management. In this teaching case, the modification of the management in a community-based museum becomes a problem-situation as it confronts two different management models. On one side, a horizontal model based in processes of team autonomy that self-connect in networks, on the other side, a more vertical and centralized model of processes and power. The focus is in an institution recognized as reference in terms of community action for the European context: the Costume Museum of São Brás de Alportel (Portugal). The dilemma allow us to understand and learn about new participative-based dynamics in the field of museum management, more specifically identifying practices for mobilization and potentialization of social participation, as well as collective competences required for shared leadership. The case seeks to contribute to the education of managers and community leaders, as they are often confronted with a lack of adequate tools for conducting a collective of project that has a cultural nature, such as the community-based museum. Furthermore, the case may be useful to individuals desiring to learn about the participative management of organizations.
\end{abstract}

Key words: participative management; museum management; social museology; participation; The Costume Museum of São Brás de Alportel.

\section{Sinopse}

A mudança de direção no Museu do Traje de São Brás de Alportel (MuT) coloca a pequena equipe local em crise e confronto com um novo modelo de gestão. O recém chegado diretor, Dr. Filipe Rêgo, possui formação e experiência profissional consolidada no desempenho da gestão clássica, vertical e centralizada de museus. Mesmo sem ser sua intenção, desencadeia uma desestruturação das dinâmicas sociais que antes sustentavam o museu. Diante da crise, a equipe decide unir-se à nova gestão para encontrar alternativas, apostando na mobilização de todos os envolvidos e na transmissão do modelo participativo, com base no trabalho em rede, num sistema horizontal de partilha de poderes e decisões, a partir do diálogo. 


\section{Objetivos didáticos}

O objetivo geral do caso é promover a compreensão e a aprendizagem das novas dinâmicas participativas no campo da gestão museal. A partir do caso, pretende-se: (a) compreender a importância da participação na gestão de iniciativas museológicas com caráter comunitário; (b) distinguir práticas de mobilização e potencialização da participação no processo de gestão museal; (c) conhecer as competências coletivas necessárias para o estabelecimento de uma liderança compartilhada; e (d) identificar os principais desafios e riscos de uma gestão participativa, comparando-os com uma gestão verticalizada.

O público-alvo do caso é variado, incluindo museólogos, líderes comunitários, gestores sociais e culturais, bem como todos os interessados em refletir e aprender sobre as questões da gestão participativa nas organizações.

\section{Sugestão para um plano de ensino}

Evidenciam-se três opções de uso deste caso dentro de um processo de aprendizagem, tendo em vista dois momentos distintos. Na opção A (Momento \#1), o caso é proposto como um ativador do compartilhamento de opiniões e vivências, a partir do entrosamento do grupo e de reflexões sobre a importância da participação em contextos organizacionais, sobretudo, como princípio base de museus comunitários.

Na opção B (Momento \#2), exige-se uma leitura prévia, de modo que o caso possa ser útil para aprofundar a reflexão sobre a participação, explorando como essa dimensão pode ser mobilizada em processos de gestão de forma mais consciente, tendo em vista aspectos importantes, como as tipologias e os níveis de participação, bem como as competências coletivas para uma liderança compartilhada.

A opção C propõe que esses dois momentos ocorram de forma sequenciada, em um mesmo processo formativo. Destaca-se a participação como dimensão importante para a gestão de uma organização, sobretudo de uma iniciativa museológica comunitária. Na opção C, o caso seria utilizado conforme orientações do primeiro momento no início da formação, e, ao seu final, recorre-se aos conhecimentos construídos no decorrer do processo, a partir das orientações do segundo momento.

\section{Opção A (Momento \#1)}

A reflexão crítica será baseada nas vivências e na bagagem de cada integrante do grupo. Dividemse os estudantes em grupos de 4 ou 5 pessoas para a leitura do caso e a realização das seguintes atividades: (a) reflexão sobre a importância da participação para a gestão do museu apresentado pelo caso; (b) identificação dos potenciais desafios e riscos relacionados à participação para a gestão do museu apresentado; (c) escuta dos relatos de experiência de cada estudante sobre situações similares, estimulando a reflexão sobre a possibilidade de mudança de lideranças e possíveis impactos em seus contextos organizacionais, no que se refere à dimensão participativa; (d) elaboração de uma sugestão de desfecho para a reunião entre a equipe e o novo diretor do museu, imaginando possíveis conversas e ações para a conclusão da história; e (e) socialização das reflexões de cada grupo (decorrentes dos 4 tópicos) com todos os estudantes da turma.

\section{Opção B (Momento \#2)}

Solicitar leitura prévia dos seguintes textos: (a) capítulo sobre princípios da participação no livro O que é participação? (Bordenave, 1983, pp. 76-81,); (b) artigo Uma escada da participação cidadã (Arnstein, 2002); e (c) artigo $\mathbf{O}$ trabalho coletivo entre líderes: ampliando a concepção do líderherói nas organizações (Cabral \& Seminotti, 2009).

As leituras prévias permitem que o professor utilize o caso para aprofundar a reflexão sobre a participação, identificando-a como dimensão possível de ser mobilizada em processos de gestão, a partir 
das questões sobre diferentes tipologias, níveis e competências necessárias para uma liderança organizacional que preze por essa dimensão. Sugere-se, portanto, retomar a mesma divisão de grupos do primeiro momento, se houver possibilidade. Caso não seja possível, refazer novos grupos de 4 a 5 pessoas, para nova leitura do caso e realização das seguintes atividades: (a) discutir e responder a Questão \#1, com base na leitura dos textos de Bordenave (1983) e Arnstein (2002); (b) discutir e responder a Questão \#2, com base na leitura do texto de Cabral e Seminotti (2009); (c) discutir e responder a Questão \#3, com base na leitura dos textos de base e das discussões anteriores; (d) propor um desfecho para caso em que haja o reestabelecimento da dinâmica participativa do grupo, a partir de ações condizentes com o perfil do novo gestor e o da equipe; e (e) apresentação e debate das respostas de cada grupo, com atenção para as mudanças de desfechos possíveis e para as suas justificativas.

\section{Questões para Discussão}

Questão \#1 - Confronte os dois modelos de gestão apresentados, identificando os possíveis tipos e níveis de participação presentes nas práticas estabelecidas pelo antigo e pelo novo diretor.

Questão \#2 - No decorrer do caso, é possível entender que o antigo gestor esforçava-se para desenvolver uma liderança compartilhada. Quais são as relações entre as competências que marcam um trabalho coletivo e as práticas evidenciadas pelo caso? Quais são os obstáculos para o desenvolvimento dessas competências no âmbito da coletividade.

Questão \#3 - O museu retratado no caso, bem como toda qualquer iniciativa comunitária, tem sua origem ligada a algum tipo de participação, tornando impossível separar a iniciativa comunitária do condicionante da participação. Entretanto, esses museus enfrentam diversos riscos quando os processos de participação são encerrados ou realizados sem um compromisso organizacional. Diante desses riscos, como a participação pode ser mobilizada e potencializada no processo de gestão do museu através de diferentes práticas?

\section{Análise do caso e conexão com a literatura}

Questão \#1 - Confronte os dois modelos de gestão apresentados, identificando os possíveis tipos e níveis de participação presentes nas práticas estabelecidas pelo antigo e pelo novo diretor.

Podemos sistematizar da seguinte forma o confronto entre os dois modelos de gestão apresentados (Tabela 1): 
Tabela 1

\section{Modelos de Gestão Museal}

\begin{tabular}{ll}
\hline $\begin{array}{l}\text { Filipe Rêgo (Novo Diretor) } \\
\text { Plano de Reestruturação de Gestão }\end{array}$ & $\begin{array}{l}\text { Álvaro Pires (Antigo Diretor) } \\
\text { Museu em Camadas }\end{array}$ \\
\hline Construção de organograma verticalizado & $\begin{array}{l}\text { Estrutura horizontal com nuances de hierarquias } \\
\text { definidas em função de fatores como a iniciativa, o } \\
\text { conhecimento da cultura local, a capacidade de trabalho } \\
\text { em equipe }\end{array}$ \\
\hline
\end{tabular}

Rigor no controle de horários da equipe com a Flexibilidade de horário como parte da cultura de instalação da máquina de ponto responsabilização e confiança em cada membro do grupo

Centralização do agendamento de visitas, uso do Atividades feitas de forma descentralizada, conforme veículo e uso dos espaços do museu necessidade, disponibilidade, conhecimento e competência

Especificação das funções e setorização do museu Flexibilidade de funções e incentivo à polivalência das competências individuais

\begin{tabular}{ll}
\hline Fechamento do museu às segundas para manutenção & Abertura do museu todos os dias do ano \\
\hline $\begin{array}{ll}\text { Fortalecimento do Traje/Indumentária/Moda como área } \\
\text { especializada e prioritária do museu }\end{array}$ & $\begin{array}{l}\text { Secundarização do acervo. Priorização da função social } \\
\text { do museu em detrimento da especificidade do seu } \\
\text { acervo. }\end{array}$
\end{tabular}

Priorização do uso de espaços unicamente a serviço de Estratégia de polivalência dos espaços para exposições acolhimento de outras demandas sociais, além da exposição

Relevância maior à equipe técnica gabaritada em Opção pela ação com a comunidade e equilíbrio entre detrimento do apoio comunitário os diversos saberes e experiências

Centralização da gestão por meio de relatório e restrição Primazia pelo fortalecimento da autonomia dos grupos à gestão das finanças e autogestão

Burocratização dos processos internos Simplificação dos processos internos

A partir desse resumo das práticas destacadas nos dois modelos de gestão, e da narrativa detalhada do caso, pode-se concluir que, enquanto o novo gestor restringe-se a níveis muito baixos de participação, ora fazendo uso da participação apenas como fonte de informação ou de consulta, o antigo diretor chega aos níveis mais altos, estimulando a autogestão e fazendo uso da delegação de poder e da cogestão ou de parcerias (Arnstein, 2002; Bordenave, 1983).

O Dr. Filipe Rêgo limita-se a uma participação manipulada, em que reúne a equipe para deliberar sobre seus objetivos, previamente estabelecidos, e não escuta, de fato, as necessidades do grupo. Limita-se a uma participação concedida, em que o grupo fica com a falsa sensação de participação, permitindo-lhe apenas um baixo grau de poder em relação à tomada de decisões (Bordenave, 1983). Ou seja, a tomada de decisão restringe-se à figura do próprio diretor.

Por outro lado, o Dr. Álvaro Pires priorizava práticas com níveis mais elevados de participação, chegando inclusive ao estímulo à autogestão de pequenos grupos organizados através do museu. Predominava, a relação de parcerias ou atividades cogeridas e à delegação de poder (Arnstein, 2002). Dessa forma, na pequena equipe, a direção buscava equilibrar as responsabilidades e estimular a autonomia para a tomada de decisões naquilo que lhes concernia, promovendo o empoderamento da equipe e da comunidade que atuava junto ao museu. Ou seja, neste modelo de gestão, passa-se da oferta das cartas do jogo, como corre com a equipe funcional e o Grupo dos Amigos, para a construção conjunta das regras do jogo, como ocorre no caso do Grupo do FMId, estimulando ambientes autogestionários, 
Questão \#2 - No decorrer do caso, é possível entender que o antigo gestor esforçava-se para desenvolver uma liderança compartilhada. Quais são as relações entre as competências que marcam um trabalho coletivo e as práticas evidenciadas pelo caso? Quais são os obstáculos para o desenvolvimento dessas competências no âmbito da coletividade?

No caso apresentado, a organização insere-se num panorama de organizações museais comprometidas com os princípios da Museologia Social. O MuT preza, portanto, por um trabalho participativo e dialógico, capaz de congregar os interesses dos diversos componentes sociais que dão vida ao museu, primando pela utilidade desse instrumento de transformação social (Sancho, 2006; Sancho-Querol \& Sancho, 2014a, 2014b, 2015a, 2015b). Assim sendo, trata-se de um exemplo de organização que explicita o "paradigma sistêmico-complexo", baseado nas relações próprias do mundo contemporâneo, "entre ordem e desordem, certezas e incertezas, controle e auto-organização", comuns em diversas situações que exemplificam essa complexidade, como é o caso da busca por "políticas e práticas que oportunizem mais espaços de participação dos trabalhadores, formação de equipes mais capacitadas e mais autônomas, bem como reconfigurações na estrutura hierárquica" das organizações (Cabral \& Seminotti, 2009, p. 19).

Nesses contextos, acredita-se que a liderança deve ser compreendida como competência coletiva. Ou seja, não se trata mais do entendimento do líder como alguém capaz de influenciar outras pessoas, mas de um processo de liderança em que todos influenciam e são influenciados mutuamente. Assim, o líder exerce sua influência no conjunto, como parte integrante dessa equipe, interdependente em relação aos demais. Nessa perspectiva, o antigo diretor do museu assume a função do gestor transversal, que centra esforços para acompanhar, facilitar e desenvolver o fluxo das competências nos processos. Isso aparece nos relatos de autonomia do grupo de fotografia (FMId) que o diretor acompanhava, que indica ligação com a capacidade de autogestão. Aparece, também, nas ações do museu que prezam pelo desenvolvimento de competências no próprio processo de fazer o museu, seja no desenvolvimento de uma exposição participativa durante dois anos na instituição, ligado à capacidade de compartilhamento e interação. Outra evidência é a integração de pessoas ao corpo do museu para o atendimento de necessidades como a conservação do acervo de trajes a partir da afinidade e da possibilidade de, ainda que voluntário, desenvolver um serviço técnico especializado com base na potencialização de competências enxergadas nesse coletivo e com base na capacidade de conexão e de ativação de heteroconhecimento (Cabral \& Seminotti, 2009).

Além disso, o caso demonstra uma lógica de gestão organizacional que opera sob a ideia de rede de cooperação independente do nível hierárquico, levando em consideração não apenas as pessoas, mas também as potencialidades do meio. Essa compreensão de rede pressupõe a capacidade de fluidez das informações e um alto grau de compartilhamento de códigos comunicacionais, que possui uma relação profunda com o desenvolvimento de uma cultura organizacional própria. No caso, é possível entender que essa sinergia se fazia presente mediante a ausência de reuniões formais para o pleno gerenciamento do museu, como se essas fossem supridas pelos encontros no café após o almoço e pela própria dinâmica das relações cotidianas. Ou seja, assim como numa rede, a competência coletiva de liderança perpassava os fios condutores e não apenas os nós do processo de gestão viva.

Entretanto, o desenvolvimento dessa competência coletiva não é algo fácil de ocorrer. Pelo contrário, possui o desafio constante de romper com a "concepção mecanicista-linear que compreende a liderança centralizada na figura do indivíduo-líder" (Cabral \& Seminotti, 2009, p. 18). A superação dessa visão dentro do paradigma sistêmico-complexo demanda, contudo, a superação também de uma série de obstáculos, dentre eles: (a) incoerências no ambiente organizacional em seus diferentes níveis hierárquicos, dificultando o entendimento de cada membro em relação ao todo, por vezes com regras e normas contraditórias; (b) deficiências na comunicação entre os componentes do grupo; (c) surgimento de relações de competição (veladas ou explícitas) no grupo, que leva a situações de não cooperação, em busca apenas da ampliação de poderes individuais, impactando de forma negativa a organização e o conjunto do grupo.

Enfim, os resquícios de modelos de gestão centralizados e mecanicistas, desenvolvidos sob uma cultura mais ampla, atrelada à competição e à hierarquização de poderes, combinados aos demais fatores 
já listados, constituem a maior dificuldade para o estabelecimento de relações de interdependência, interconectividade, flexibilidade e maleabilidade que caracterizam a formação de redes. Estas, por sua vez, são tidas como espaços favoráveis ao desenvolvimento da liderança como competência coletiva, pois permitem pensar a organização de forma processual, "inerente às propriedades da complexidade sistêmica do mundo contemporâneo" (Cabral \& Seminotti, 2009, p. 25).

Questão \#3 - O museu retratado no caso, bem como toda e qualquer iniciativa comunitária, tem sua origem ligada a algum tipo de participação, tornando impossível separar a iniciativa comunitária do condicionante da participação. Entretanto, tais museus enfrentam diversos riscos quando os processos de participação são encerrados ou realizados sem um compromisso organizacional. Diante desses riscos, como a participação pode ser mobilizada e potencializada no processo de gestão do museu através de diferentes práticas?

Trabalha-se com a ideia de que a participação pode ser instrumental, tratada como um valor ou como um princípio pela Museologia Social. Por isso, deve ser mobilizada para a gestão adequada dessas organizações. Podemos evidenciar algumas "ferramentas operativas da participação" (Bordenave, 1983, p. 64).

O conhecimento da realidade. Para o desenvolvimento de um ambiente participativo, é necessário que o gestor/mediador conheça a realidade em que atua. Na perspectiva do antigo diretor, no caso do Museu do Traje, havia a busca pelo conhecimento prévio da comunidade local, dos seus anseios e de suas necessidades. A partir desse conhecimento, ações eram desenvolvidas de forma a convocar essa população à participação. Isso é evidenciado pela fala de Vera ao apontar o entendimento da polivalência dos espaços do museu como uma estratégia para o acolhimento e para a aproximação do público local, tendo em vista uma demanda apresentada pelos mesmos na ocasião inicial do Grupo de Amigos do Museu.

Entretanto, nem sempre a demanda será apresentada pela comunidade ao museu. Dessa forma, faz-se necessário que o museu, ou a organização, esteja atento e procure conhecer a diversidade do seu contexto local, através da pesquisa, ou seja, significa dizer que os agentes do museu serão também agentes de pesquisa local (Bordenave, 1983). Ao pesquisarem, entretanto, não há a preocupação dos academicismos, mas, sim, o entendimento da ação de pesquisa como uma ação também participativa. Observa-se, portanto, que o novo diretor que chega ao museu, apesar de uma postura de liderança mais centralizadora, com menos aspectos de autonomia, ressalta a necessidade de conhecer em boa parte de suas falas diante do grupo. Essa postura pode ser mobilizada em favor do reestabelecimento de uma dinâmica participativa do museu, conduzindo o novo diretor ao conhecimento da realidade local, seja através de uma pesquisa mais formal, do diálogo com moradores e utilizadores do museu, entre outros. Ou seja, faz-se do conhecimento local um instrumento de ativação da participação.

A comunicação. Sem uma comunicação de qualidade e eficaz, a participação será sempre limitada. De modo contrário, fazendo uso de processos comunicativos, a participação pode ser potencializada. No caso, muitas situações de comunicação são relatadas, porém, daremos aqui ênfase em três tipos de comunicação: processos informativos, processos de diálogo e processos educativos.

Como processo informativo, exemplificamos a reunião de apresentação do novo diretor. Entendemos que a partir da informação, um tipo de processo de conhecimento pode ser gerado. Através de um processo informativo eficaz, as pessoas poderão refletir e saber onde e como se colocar (Bordenave, 1983). Entretanto, se a comunicação se resumir apenas a processos informativos, a participação permanecerá limitada. É preciso que a informação seja direcionada corretamente, que caminhos estejam abertos para o processamento e a transformação dessa informação em novos conhecimentos, caminhos estes que podem ser gerados por outras práticas comunicativas, como o diálogo e processos educativos.

O processo de diálogo, exemplificado pelas reuniões entre o novo diretor e a equipe do museu, é evidenciado como uma das maiores estratégias para a participação e para o gerenciamento de conflitos, tão comuns em contextos comunitários. A comunicação, nesse aspecto, demanda ao gestor/mediador a 
escuta ativa e o estabelecimento do diálogo entre as diferentes partes do grupo, ou pontos de conflito. O diálogo, além de cooperar para a busca do consenso, para encontrar uma solução aceitável para todos, possibilita também um outro potencial comunicativo para a dinâmica participativa, o qual está relacionado também com as competências coletivas da liderança compartilhada - trata-se do estabelecimento de redes, de inter-relações mais complexas, porém que detenham possibilidades de apresentar soluções a questões mais complexas e estruturais também (Cabral \& Seminotti 2009).

Partindo do exercício da rede, já recaímos em um outro processo, que, apesar de ser tratado como comunicativo aqui, transcende a dimensão puramente comunicativa, e passa a ser um processo educativo. Além do próprio exemplo da formação de redes de cooperação, ao voltar para o caso, temos também o exemplo da construção de uma exposição colaborativa na gestão do antigo diretor. Trata-se de uma comunicação que pressupõe o processo educativo - "só se aprende a participar, participando" (Bordenave, 1983, p. 74). Na construção colaborativa da exposição, as pessoas são postas em situações que demandam a sua participação de forma inserida na própria dinâmica do museu. Ou seja, as opiniões não foram ouvidas estritamente em reuniões, em momentos pontuais preparados para que houvesse essa participação, mas foi trabalhada de forma orgânica pelo museu para que as sugestões e a participação fosse prevista no cotidiano, ainda que se tenha demorado dois anos para a consecução da exposição.

A participação, portanto, é aprendida. E, entre os que participam, tende a construir a ideia de equipe, e esta, por sua vez, "possibilita a construção de um sentimento de identidade, que permite potencializar a interdependência e os resultados em conjunto" (Cabral \& Seminotti 2009, p. 22), realimentando a dinâmica da participação.

O modelo organizacional. A estrutura e o modelo organizacional são outro instrumento que pode ser operacionalizado em favor da mobilização da participação e da construção de competências coletivas para lideranças compartilhadas. A começar, num museu comunitário, ou numa organização comunitária devem ser pressuposto básico formas de lideranças menos hierárquicas, menos centralizadas, ou seja, com maior abertura para a participação da própria comunidade. Bordenave $(1983$, p. 68) afirma que a "organização não é um fim em si mesma, mas uma condição necessária para a participação transformadora".

Dessa forma, a própria estrutura e a dinâmica organizacional devem ser coerentes com o tipo de liderança que se preza. No caso, há o relato de uma instituição formal, e do impasse decorrente da hierarquia proveniente da própria natureza da Fundação à qual o Museu está ligado. Isso pode ser percebido na questão de implantação do ponto, como também da busca do novo gestor pela centralização das informações, do acervo, das atividades, dos espaços e dos recursos. O exercício de um tipo de liderança compartilhada pelo antigo gestor enfrentava os fatores críticos que o desenvolvimento de competências coletivas que a atual liderança enfrenta, justamente em decorrência desse pensamento predominante do modelo linear, mecanicista e hierarquizado (Cabral \& Seminotti, 2009), que subsidia a própria Fundação.

\section{Indicações Bibliográficas}

Cândido, M. D. (2013). Gestão de Museus, um desafio contemporâneo: Diagnóstico museológico e planejamento. Porto Alegre: Medianiz.

Carpentier, N. (2012). The concept of participation. If they have access and interact, do they really participate? Revista Fronteiras - Estudos Midiáticos, 14(2), 164-17. http://dx.doi.org/10.4013/fem.2012.142.10

Chagas, M., \& Gouveia, I. (2014). Museologia social: Reflexões e práticas. Cadernos do CEOM, Ano 27(41), 9-22. 
Davel, E., \& Vergara, S. C. (2005). Desafios relacionais nas práticas de gestão e de organização. Revista de Administração de Empresas, 45(1), 10-13. http://dx.doi.org/10.1590/S003475902005000100002

Gianella, V., \& Moura, M. S. (2009). Gestão em rede e metodologias não convencionais para a gestão social (Vol. 2, Coleção Roteiros Gestão Social). Salvador: Editora CIAGS.

Lersch, T. M., \& Ocampo, C. (2009). Manual para la creación y desarrollo de museos comunitarios. Bolivia: Artes Graficas Sagitario Srl.

Machado, V. (2016). DGCC - Diálogo e gestão criativa de conflitos - um método centrado na complexidade do pensamento e simplicidade da ação. Lauro de Freitas: Editora Solisluna.

Nunes, D. (2006). Pedagogia da participação: Trabalhando com comunidades. Salvador: UNESCO/Quarteto.

Watson, T. J. (2005). Organização e trabalho em transição: Da lógica "sistêmico-controladora" à lógica "processual-relacional". Revista de Administração de Empresas, 45(1), 14-23. http://dx.doi.org/10.1590/S0034-75902005000100003

\section{Agradecimentos}

Agradecemos a Fundação de Amparo à Pesquisa do Estado da Bahia (FAPESB) e ao Programa Professor Visitante do Exterior (n. 036/2013) da CAPES, pelo apoio a pesquisa.

\section{Referências}

Arnstein, S. R. (2002, janeiro). Uma escada da participação cidadã. Revista da Associação Brasileira para o Fortalecimento da Participação - PARTICIPE, 2(2), 4-13.

Bordenave, J. E. D. (1983). O que é participação? São Paulo: Ed. Brasiliense.

Cabral, P. M. F., \& Seminotti, N. (2009, setembro). O trabalho coletivo entre líderes: ampliando a concepção do líder-herói nas organizações. Revista da SBDG, (4),18-28. Recuperado de http://www.sbdg.org.br/admin/revistas/revista3.zip

Sancho, E. (2006, maio). Museu do Trajo de S. Brás de Alportel: Uma experiência particular. Revista Museal, n. 1, p. 56-63.

Sancho-Querol, L., \& Sancho, E. (2014a). Imagens que valem mil palavras: A experiência do arquivo de memórias do Museu de São Brás. Cadernos de Sociomuseologia, 48(4), 7-34. Recuperado de http://revistas.ulusofona.pt/index.php/cadernosociomuseologia/article/view/4627

Sancho-Querol, L., \& Sancho, E. (2014b). Sujeitos do património: Os novos horizontes da museologia social em São Brás de Alportel. E-cadernos ces, (21). Recuperado de http://eces.revues.org/1780. http://dx.doi.org/10.4000/ eces. 1780

Sancho-Querol, L., \& Sancho, E. (2015a). How can museums contribute to social and cultural change? In J. T. Jensen \& I. B. Lundgaard (Coords.), Museums: Citizens and sustainable solutions (pp. 212-231). Denmark: Danish Agency for Culture. 
Sancho-Querol, L., \& Sancho, E. (2015b). MuT: Connecting people, ideas and worlds to build a useful museology. In H. Pinto (Ed.), Resilient territories: Innovation and creativity for new modes of regional development (pp. 188-206). Cambridge, UK: Cambridge Scholars Publishing.

\section{Dados dos Autores}

Hilda Barbara Maia Cezário

Rua Dr. José Dias Sancho, 61, 8150-141, São Brás de Alportel, Portugal. E-mail: hbarbaramaia@gmail.com

Eduardo Davel

Av. Reitor Miguel Calmon, S/N, 40110-903, Salvador, BA, Brasil. E-mail: davel.eduardo@ gmail.com

Lorena Sancho Querol

Colégio de S. Jerónimo, Largo D. Dinis, Apartado 3087, 3000-995, Coimbra, Portugal. E-mail: lorenaquerol@ gmail.com

Emanuel Sancho

Rua Dr. José Dias Sancho, 61, 8150-141, São Brás de Alportel, Portugal. E-mail: emanuel@ museu-sbras.com 